УДК [378.147:796.011.3]:004

\author{
І.Б. ГРИНЧЕНКО, О.В. РІЗНИК, В.В. ЛИСЕНКО,
} В.М. КОВЕРЯ, Т.В. КАРПУНЕЦЬ

\title{
ПІДВИЩЕННЯ ЕФЕКТИВНОСТІ ФІЗИЧНОЇ Й ТЕХНІЧНОЇ ПІДГОТОВЛЕНОСТІ ЮНИХ ГАНДБОЛІСТІВ ІЗ ЗАСТОСУВАННЯМ РУХЛИВИХ ІГОР
}

\author{
(C) Гринченко I.Б., 2020 \\ http://orcid.org/0000-0001-7469-5819 \\ (C) Різник О.В., 2020 \\ https://orcid.org/0000-0002-3229-8150 \\ (C) Лисенко В.В., 2020 \\ https://orcid.org/0000-0002-9765-1808 \\ (C) Ковєря В.М., 2020 \\ https://orcid.org/0000-0001-6103-1423 \\ (C) Карпунець Т.В., 2020 \\ https://orcid.org/0000-0002-9579-1794 \\ http://doi.org/10.34142/2312-2471.2020.63.04
}

Статтю присвячено дослідженню ефективності фізичної та технічної підготовленості юних гандболістів 10-11 років засобами рухливих ігор, ігрових вправ та естафет на етапі початкової підготовки. У роботі стверджується, щуо для підвищення фізичної $i$ технічної підготовленості юних гандболістів необхідно правильно підібрати комплекс ігор, вправ, прийомів. 3'ясовано, щуо такі комплекси викликають у дітей ігровий азарт, захоплюють своєю напругою й пристрастю, викликають додаткові позитивні психологічні емочї, сприяють формуванню у юних спортсменів можливості творчих, імпровізаційних дій на спортивному майданчику. Рухливі ігри доцільно підбирати з метою організації розминки, для розвитку сили, швидкісних якостей та швидкості рухів, для тренування спритності, витривалості й гнучкості. Різноманітність комбінацій, застосовуваних на тренуваннях 3 рухливих ігор з фізичного навантаження і координаційної складності взаємодії учасників має бути доступною. Головна відмінність застосування рухливих ігор на заняттях з юними гандболістами полягає в тому, щзо заняття сприймаються з величезною радістю, проходять з більшою віддачею $i$ на високому емоиійному рівні. У роботі пропонується авторська методика, яка передбачала впровадження в навчально-тренувальний процес юних гандболістів 10-11 років, групи початкової підготовки (експериментальної групи), рухливих ігор, естафет та ігрових завдань. Методика впроваджувалася протягом 9 місяців (74 заняття), 3 рази на тиждень, тривалістю 20 хв. Особливістю авторської методики було те, щзо ігри поділялися на дві групи: перша група - рухливі ігри для розвитку основних фізичних якостей юних 
гандболістів; друга група - рухливі ігри для відпрацюювання технічних $i$ тактичних навичок гри. Після проведення експерименту з'ясувався статистично значимий приріст показників рівня фізичної підготовленості, щзо зафіксовано тільки у випробовуваних експериментальної групи, які займалися за авторською методикою. Крім визначення показників фізичної підготовленості гандболістів за результатами тестування здійснювався аналіз технічної підготовленості обстежуваних, щуо виявило також достовірний приріст.

Ключові слова: фізична підготовленість, технічна підготовленість, юні гандболісти, рухливі ігри, ігрових вправи, естафети

\section{Hrynchenko I., Riznyk O., Lysenko V., Kovieria V., Karpunets T. Improving} the Efficiency of Physical and Technical Training for Young Handball Players Using Moving Games

The article is devoted to the effectiveness of physical and technical training for young handball players aged 10-11 by means of moving games, exercises and relay races at the stage of initial training. The paper argues that it is necessary to choose the correct kit of games, exercises, techniques to improve physical and technical training of young handball players. It was found that such complexes help children to play with excitement, capture their tension and passion, add extra positive psychological emotions, and contribute to young athletes' development for creative opportunity, improvisational actions on the playground. It is necessary to select moving games for warm-up purposes, force development, speed qualities and speed movements, dexterity training, endurance and flexibility. The variety of combinations used in training with mobile games on physical activity and coordination complexity of participants' interaction should be available. The main difference between the use of moving games in classes with young handball players is that the classes are perceived with great joy, held with greater impact and at a high emotional level. The authors' technique is offered in the work, it was provided for the introduction of young handball players aged 10-11, initial training groups (experimental group), moving games, relay races and game tasks into the educational and training process. The technique had been implemented for 9 months (74 lessons), 3 times a week, lasting 20 minutes. The peculiarity of the authors' method was that the games were divided into two groups: the first group offered mobile games for the development of basic physical qualities of young handball players; the second group offered mobile games to practice technical and tactical skills with games. After the experiment there was a statistically significant increase in the level of physical training, which was only in the experimental group with the authors' method. In addition to determining the indicators of physical training of handball players based on the test results, the analysis of the technical training was carried out, it also showed a significant increase.

Keywords: physical training, technical training, young handball players, moving games, game exercises, relay races 
Постановка проблеми. Проблема підготовленості юних гандболістів 1011 років відповідно до ігрових амплуа набуває сьогодні актуального значення. Про це вказують сучасні дослідники (В. Ігнатьева [4], А. Кубраченко [10], Ю. Любовський [12]). Дійсно, підготовка висококваліфікованого гандболіста займає не менш 6-10 років [3]. Для підвищення фізичної i технічної підготовленості юних гандболістів необхідно, перш за все, правильно підібрати комплекс прийомів, якими можна оволодіти в найкоротший час. Однак, на сучасному етапі розвитку спортивної науки, як підкреслює в своєму дослідженні В.Корягін [8], нерідко зустрічаються категоричні й малообгрунтовані заклики до «універсалізації» гравців або, навпаки, пропонується їхня рання спеціалізація.

Відомі західні фахівці (В. Abernethy, J. Baker, Y. Calvin, J. Côté, E. Duprat, Ph.Leroux, J. Waty) наполягають на тому, що проблема універсалізації чи спеціалізації гравців, в тому числі й гандболістів, безумовно, потребує вирішення. Для цього потрібні теоретичні та практичні дослідження, але, на жаль, фундаментальних наукових праць, а також пропонованих авторських методик, в цій галузі поки що недостатньо.

Таким чином, це створює протиріччя між підвищенням вимог до рівня фізичної підготовленості юних гандболістів, з одного боку, і недостатністю існуючих авторських методик щодо розвитку фізичних якостей гравців, - 3 іншого боку. Визначене протиріччя актуалізує проблему підвищення ефективності фізичної й технічної підготовленості гандболістів 3 використанням, у нашому випадку - авторської методики, спеціально підібраних рухливих ігор, ігрових завдань та естафет.

Аналіз останніх досліджень і публікацій. Деякі аспекти досліджуваної проблеми висвітлені в працях таких учених, як Г. Безверхня [1], О. Корносенко [6], О. Кругляк [9], С. Карасевич [5] та інших.

Як зазначають дослідники О. Корносенко, В. Бондаренко, П. Хоменко [6], навчально-тренувальні заняття з елементами рухливих ігор, ігрових вправ та естафет викликають у дітей ігровий азарт, захоплюють своєю напругою й пристрастю, викликають додаткові позитивні психологічні емоції, сприяють формуванню у юних спортсменів можливості творчих, імпровізаційних дій на спортивному майданчику.

Деякі автори С. Карасєвич, М. Карасєвич [5] вважають, що рухливі ігри доцільно підбирати 3 метою організації розминки, для розвитку сили, швидкісних якостей та швидкості рухів, для тренування спритності, витривалості й гнучкості, а також для організації активного відпочинку після інтенсивного i напруженого тренування. О. Кругляк [9] доводить, що за допомогою рухливих ігор можна ефективно виховувати дисциплінованість, колективізм і розвивати складну взаємодію всіх гравців команди.

При плануванні рухливих ігор, наголошують Г. Безверхня, А. Семенов, М. Килимистий, Р. Маслюк [1], слід враховувати загальне навантаження в окремому занятті й, відповідно, визначати їх основну мету і місце серед інших вправ і завдань. Різноманітність комбінацій, застосовуваних на тренуваннях 3 
рухливих ігор з фізичного навантаження і координаційної складності взаємодії учасників має бути доступною для дітей і зростати поступово.

Іноземні вчені J.Guerrero [16], S. Hjorth [17] у своїх дослідженнях підкреслюють, що включення в урок фізкультури рухливих ігор з елементами гандболу дозволяють швидше освоїти два найважливіших технічних прийоми гри: ловлю і кидок.

Як зазначають відомі фахівці Ж.Козіна [15], В.Левкін [11], А.Попович [13] використання рухливих ігор на заняттях 3 гандболу є найбільш дієвим засобом фізичного розвитку і різнобічного виховання рухових якостей юних спортсменів. Головна особливість використання рухливих ігор на заняттях 3 юними гандболістами полягає в тому, що заняття сприймаються з величезною радістю, проходять з більшою віддачею і на високому емоційному рівні.

Проте недостатньо вивченими залишається дослідження авторських методик використання рухливих ігор на заняттях з юними гандболістами.

Формулювання цілей статті. Мета дослідження - підвищення ефективності фізичної та технічної підготовленості юних гандболістів 10-11 років засобами рухливих ігор, ігрових вправ та естафет на етапі початкової підготовки.

Методи, учасники і організація дослідження. В ході дослідження були використані наступні методи: теоретичний аналіз і узагальнення науковометодичної літератури, контрольно-педагогічні випробування (тести), педагогічні спостереження, антропометрія.

Виклад основного матеріалу. На початку експерименту за стандартними методиками було проведено тестування показників фізичного розвитку та рівня загальної фізичної і технічної підготовленості випробовуваних. Отримані в результаті дослідження дані оброблялися за допомогою методів математичної статистики. Статистична обробка експериментальних даних здійснювалася 3 використанням пакета статистичної обробки STATGRAPHICS Plus for Windows (згідно стандартними методиками). Статистично достовірними вважалися результати при $\mathrm{p}<0,05$.

В дослідженні взяли участь юні гандболісти 10-11 років, першого та другого року навчання К3 «КДЮСШ №3» м. Харкова, яких ми поділили на дві групи: експериментальну та контрольну. Дослідження тривало протягом року.

Авторська методика передбачала впровадження в навчальнотренувальний процес юних гандболістів 10-11 років, групи початкової підготовки (експериментальної групи), рухливих ігор, естафет та ігрових завдань. Методика впроваджувалася протягом 9 місяців (74 заняття), 3 рази на тиждень, тривалістю 20 хв.

Протягом усіх тренувальних занять відбувалася зміна комбінацій використання рухливих ігор. Незмінним залишався лише обраний елемент техніки гандболу, який відповідав цілям і задачам відповідного етапу навчання.

Спираючись на загальні рекомендації використання рухливих ігор й ігрових вправ у фізичному вихованні дітей шкільного віку [2], особливістю авторської методики було те, що ми ці ігри поділили на дві групи: перша група - рухливі ігри для розвитку основних фізичних якостей юних гандболістів; 
друга група - рухливі ігри для відпрацювання технічних і тактичних навичок гри.

Такий розподіл, звичайно ж, носив умовний характер, оскільки кожна гра дозволяє тренеру вирішувати багатопланові завдання, спрямовані на виховання у підопічних i фізичних, i особистісних якостей, на формування i техніки, i тактики поведінки на гандбольної майданчику.

До першої групи ми включили:

Ігри для розвитку рухливо-координаційних якостей («Кидай першим», «Влуч у уціль», «Два капітани», «Хто перший», «М'яч тому, хто водить», «Хто далі», «Влуч у кошик», «М'ячі в кошик», «Кращий снайпер»).

Ігри для розвитку сили («М'яч за стінкою», «Півняча атака», «Морський бій», «Прорвися в зону», «Кидай далі», «Перехопи м’яч», «Утримайся в колі», «Тісне коло», «Бій півнів»).

Ігри для розвитку витривалості («Ведучий по колу», «Приземли м’яча», «Біатлон з відбиванням», «Регбі-футбол», «Даєш бали», «Ми танцюємо».

Ігри для розвитку витривалості ми здійснювали наприкінці основної частини занять у другій половині тижня, тобто в четвер-п'ятницю.

Ігри для розвитку прудкості («Квач 3 передачами», «Доганялки», «Стримай м'яч», «Дуелянти», «Найбільш швидкі», «Хто швидше», «Швидко по місцях», «Виклик номерів», «Комбінована естафета», «Ланцюжок», «Чорне i біле», «День і ніч», «Третій зайвий»).

Ігри для розвитку спритності та гнучкості («Рибалки й рибки», «Ведіння м’ячів», «Горобці й кішка», «Квач», «Естафета», «Змагання в колі», «Стрибуча колона», «Стоніжка», «Місток і кішка»).

Ігрові вправи на спритність і гнучкість ми використовували на всіх без винятку заняттях. Найчастіше їх включали у підготовчу частину занять.

До другої групи ми включили рухливі ігри та естафети, спрямовані на формування техніко-тактичних навичок гри в гандбол («Захист флангу», «Пройди захисника», «Боротьба за м’яч», «Два табори», «Один проти одного», «Один проти двох», «Гандбол з обмеженням», «М'яч із чотирьох сторін», «Квач i м'яч», «Перехопи м'яч», «Захист фортеці», «Кидки м'яча під мотузкою», «Кидки м'яча над мотузкою»).

Організація занять 3 юними гандболістами контрольної групи, а також вибір форм, засобів і методів навчання, дозування навантаження здійснювалося відповідно до методичних рекомендацій, викладених у навчальній програмі для дитячо-юнацьких спортивних шкіл, спеціалізованих дитячо-юнацьких шкіл олімпійського резерву, шкіл вищої спортивної майстерності [2].

Отже, пропонуємо методичне обгрунтування використання рухливих ігор в авторський методиці тренування. Пропоновані нами рухливі ігри розроблені й включені в авторську методику. Вони призначені для освоєння програмного матеріалу з гандболу й спрямовані, перш за все, на виховання основних фізичних якостей, розвиток творчих здібностей, а також на відпрацювання найважливіших технічних прийомів гри (переміщень, передач, ловлі, кидків м'яча тощо). 
Ще одна важлива особливість, використаних у дослідженні рухливих ігор й ігрових вправ, полягає в тому, що вони мотивують дітей боротися за перемогу, а прагнення до перемоги викликає необхідність вдосконалюватися і в техніці, й в тактиці гри. Крім того, участь в іграх вимагає від юних гандболістів певної фізичної підготовки. Уміло поєднуючи рухливі ігри з іншими вправами i завданнями, тренер досягає більш свідомого ставлення підопічних до гандбольної гри.

Результати власних досліджень. Ми стверджуємо, що фізична підготовленість гандболіста тісно пов'язана з різними сторонами підготовки. Обрані тести досить повно характеризують фізичний розвиток i функціональний стан основних життєзабезпечуючих систем організму i дозволяють визначити ефективність запропонованої методики (табл. 1,2 ).

В ході нашого дослідження достовірних відмінностей з всього комплексу морфологічних показників, які використовуються в експерименті, не було виявлено.

Таблиця 1

МОРФОЛОГІЧНІ ПОКАЗНИКИ ГАНДБОЛІСТІВ КОНТРОЛЬНОЇ І ЕКСПЕРИМЕНТАЛЬНОЇ ГРУП ДО ПОЧАТКУ ПРОВЕДЕННЯ ПЕДАГОГІЧНОГО ЕКСПЕРИМЕНТУ $(\mathrm{X} \pm \mathrm{M})$

\begin{tabular}{|l|c|c|c|c|c|}
\hline № & Параметр & $\begin{array}{c}\text { Контрольна } \\
\text { група }(n=11)\end{array}$ & $\begin{array}{c}\text { Контрольна } \\
\text { група }(n=11)\end{array}$ & $t$ & $P$ \\
\hline 1. & Довжина тіла, см & $155,71 \pm 1,86$ & $157,14 \pm 2,07$ & 0,51 & $>0,05$ \\
\hline 2. & Маса тіла, кг & $42,21 \pm 1,53$ & $40,87 \pm 1,22$ & 0,69 & $>0,05$ \\
\hline 3. & $\begin{array}{c}\text { Окружність } \\
\text { грудної клітини } \\
\text { (ОГК), см }\end{array}$ & $8,86 \pm 1,48$ & $69,14 \pm 1,71$ & 0,13 & $>0,05$ \\
\hline
\end{tabular}

Таблиця 2 ПРИРІСТ МОРФОЛОГІЧНИХ ПОКАЗНИКІВ ЮНИХ ГАНДБОЛІСТІВ ПІСЛЯ ЕКСПЕРИМЕНТУ

\begin{tabular}{|c|c|c|c|c|c|c|c|c|c|}
\hline \multirow[b]{2}{*}{ № } & \multirow[b]{2}{*}{ Параметр } & \multicolumn{4}{|c|}{ Контрольна група $(n=11)$} & \multicolumn{4}{|c|}{$\begin{array}{c}\text { Експериментальна } \\
\text { група }(n=11)\end{array}$} \\
\hline & & $\begin{array}{c}\text { До } \\
\text { експери } \\
\text { менту }\end{array}$ & $\begin{array}{c}\text { Після } \\
\text { експери } \\
\text { менту }\end{array}$ & $t$ & $P$ & $\begin{array}{c}\text { До } \\
\text { експери } \\
\text { менту }\end{array}$ & $\begin{array}{l}\text { Після } \\
\text { експери } \\
\text { менту }\end{array}$ & $\mathrm{t}$ & $P$ \\
\hline 1. & $\begin{array}{r}\text { Довя } \\
\text { тіла }\end{array}$ & $\begin{array}{c}155,71 \\
\pm 1,86\end{array}$ & $\begin{array}{c}158,71 \\
\pm 1,78\end{array}$ & 1,17 & $>0,05$ & $\begin{array}{l}157,14 \\
\pm 2,07\end{array}$ & $\begin{array}{l}162,14 \\
\pm 2,07\end{array}$ & 1,1 & $>0,05$ \\
\hline 2. & $\begin{array}{c}\text { Маса } \\
\text { тіла, кг }\end{array}$ & $\begin{array}{c}2,21 \pm \\
1,53\end{array}$ & $\begin{array}{l}44,29 \\
\pm 1,05\end{array}$ & 1,12 & $>0,05$ & $\begin{array}{l}40,87 \\
\pm 1,22\end{array}$ & $\begin{array}{l}43,21 \\
\pm 0,85\end{array}$ & 1,57 & $>0,05$ \\
\hline 3. & ОГК, см & $\begin{array}{c}8,86 \pm \\
1,48\end{array}$ & $\begin{array}{c}70,0 \\
\pm 1,41\end{array}$ & 0,60 & $>0,05$ & $\begin{array}{l}69,14 \\
\pm 1,71\end{array}$ & $\begin{array}{l}74,54 \\
\pm 1,50\end{array}$ & 2,36 & $<0,05$ \\
\hline
\end{tabular}

Проте порівняльний аналіз приросту результатів за період експерименту показав, що значне поліпшення і зміна в стані відбулася у дітей 
експериментальної групи. Результати, отримані за підсумками дослідження показників фізичної підготовленості, представлені в табл. 3.

Таблиця 3

ПРИРІСТ ПОКАЗНИКІВ ФІЗИЧНОЇ ПІДГОТОВЛЕНОСТІ ЮНИХ ГАНДБОЛІСТІВ ПІСЛЯ ДРУГОГО ЕТАПУ ЕКСПЕРИМЕНТУ

\begin{tabular}{|c|c|c|c|c|c|c|c|c|c|}
\hline & \multirow[b]{2}{*}{ Тест } & \multicolumn{4}{|c|}{ Контрольна група $(n=11)$} & \multicolumn{4}{|c|}{$\begin{array}{c}\text { Експериментальна } \\
\text { група }(n=11)\end{array}$} \\
\hline & & $\begin{array}{c}\text { До } \\
\text { експери } \\
\text { менту }\end{array}$ & $\begin{array}{c}\text { Після } \\
\text { експер } \\
\text { именту }\end{array}$ & $t$ & $P$ & \begin{tabular}{|c|} 
До \\
експери \\
менту
\end{tabular} & $\begin{array}{c}\text { Після } \\
\text { експери } \\
\text { менту }\end{array}$ & $t$ & $P$ \\
\hline 1. & $\begin{array}{c}\text { Стрибок } \\
\text { в } \\
\text { довжину } \\
\text { з місця, } \\
\text { см }\end{array}$ & $\begin{array}{l}164,17 \\
\pm 3,52\end{array}$ & $\begin{array}{l}171,51 \\
\pm 4,40\end{array}$ & 1,30 & $\begin{array}{l}>0,0 \\
5\end{array}$ & $\begin{array}{l}163,04 \\
\pm 3,74\end{array}$ & $\begin{array}{l}177,71 \\
\pm 4,07\end{array}$ & 2,65 & $<0,05$ \\
\hline 2. & $\begin{array}{l}\text { Стрибок } \\
\text { вгору,см } \\
\end{array}$ & $\begin{array}{l}35,51 \\
\pm 1,92 \\
\end{array}$ & $\begin{array}{l}39,07 \\
\pm 2,11 \\
\end{array}$ & 1,25 & $\begin{array}{c}>0,0 \\
5\end{array}$ & $\begin{array}{l}35,11 \\
\pm 1,71 \\
\end{array}$ & $\begin{array}{l}41,78 \\
\pm 1,14 \\
\end{array}$ & 2,63 & $<0,05$ \\
\hline 3. & $\begin{array}{c}\text { Човнико } \\
\text { вий біг } \\
3 \times 10, c\end{array}$ & $\begin{array}{c}8,86 \\
\pm 1,48\end{array}$ & $\begin{array}{c}70,0 \\
\pm 1,41\end{array}$ & 0,60 & $\begin{array}{l}>0,0 \\
5\end{array}$ & $\begin{array}{c}8,89 \\
\pm 0,22\end{array}$ & $\begin{array}{c}8,32 \\
\pm 0,09\end{array}$ & 2,31 & $<0,05$ \\
\hline 4. & $\begin{array}{c}\text { 6- } \\
\text { хвилинн } \\
\text { ий біг, м }\end{array}$ & $\begin{array}{c}1006 \\
\pm 62,17\end{array}$ & $\begin{array}{c}1120 \\
\pm 109,5 \\
4\end{array}$ & 0,91 & $\begin{array}{l}>0,0 \\
5\end{array}$ & $\begin{array}{c}1000 \\
\pm 26,53\end{array}$ & $\begin{array}{c}1310,93 \\
\pm 64,39\end{array}$ & 4,46 & $<0,01$ \\
\hline 5. & $\begin{array}{c}\text { Нахил } \\
\text { вперед, } \\
\text { см } \\
\end{array}$ & $\begin{array}{c}2,31 \\
\pm 1,16\end{array}$ & $\begin{array}{c}3,24 \\
\pm 1,21\end{array}$ & 0,55 & $\begin{array}{l}>0,0 \\
5\end{array}$ & $\begin{array}{c}2,71 \\
\pm 1,19\end{array}$ & $\begin{array}{c}2,71 \\
\pm 1,19\end{array}$ & 3,37 & $<0,01$ \\
\hline 6. & $\begin{array}{c}\text { «Лінійка } \\
\text { » }\end{array}$ & $\begin{array}{l}19,95 \\
\pm 2,25\end{array}$ & $\begin{array}{l}16,92 \\
\pm 4,28\end{array}$ & 0,63 & $\begin{array}{l}>0,0 \\
5\end{array}$ & $\begin{array}{l}20,79 \\
\pm 2,37\end{array}$ & $\begin{array}{l}11,36 \\
\pm 2,79\end{array}$ & 2,58 & $<0,05$ \\
\hline
\end{tabular}

Аналіз значень засвідчив, що сучасна спортивна підготовка гандболістів $€$ багатокомпонентною системою. За переважною спрямованістю прийнято виділяти дві групи видів підготовки: аналітичну й інтегральну.

До аналітичної підготовки відносять фізичну, технічну, тактичну, психологічну, теоретичну підготовленість; до інтегральної - ігрову, проблемноситуаційну і змагальну.

Виявлено, що гравці на етапі початкового навчання повинні володіти специфічним для гандболу (відповідним, достатнім), а не абсолютним рівнем розвитку фізичних здібностей. Пріоритетне значення на етапі початкової спеціалізації необхідно відводити розвитку загальної витривалості, швидкісносилових здібностей, координації й гнучкості гравців.

Статистично значимий приріст показників рівня фізичної підготовленості за підсумками експерименту зафіксовано тільки у випробовуваних, які займалися за авторською методикою. Відсотковий приріст розраховувався за 
загальновідомою формулою (В-A)/ А * 100, де А - початкові результати тестування до експерименту; В - кінцеві результати тестування після експерименту.

Показники у стрибку в довжину після закінчення експерименту зросли на 8,9\%, стрибка вгору - на 19\%. Показники координаційних здібностей, які проявляються за результатами човникового бігу і тесту «лінійка» достовірно зросли тільки в експериментальній групі, приріст склав 6,4\% i 45,3\% відповідно. Значний приріст показників фізичної підготовленості стався в експериментальній групі в тестовому завданні: 6-хвилинної бігу - понад $31,1 \%$.

У нашому експерименті крім визначення показників фізичної підготовленості гандболістів за результатами тестування здійснювався аналіз технічної підготовленості обстежуваних. Результати даного дослідження представлені в табл. 4, де підсумкові показники технічної підготовленості експериментальної групи виявили достовірний приріст, відповідний 5\%-му рівню значущості за показниками штрафних кидків і пересування в захисній стійці гандболіста.

Таблиця 4

ПОКАЗНИКИ ТЕХНІЧНОЇ ПІДГОТОВЛЕНОСТІ ЮНИХ ГАНДБОЛІСТІВ ПІСЛЯ ДРУГОГО ЕТАПУ ЕКСПЕРИМЕНТУ

\begin{tabular}{|c|c|c|c|c|c|c|c|c|c|}
\hline & \multirow{2}{*}{ Тест } & \multicolumn{4}{|c|}{ Контрольна група $(n=11)$} & \multicolumn{4}{|c|}{$\begin{array}{c}\text { Експериментальна } \\
\text { група }(n=11)\end{array}$} \\
\hline & & $\begin{array}{c}\text { До } \\
\text { експери } \\
\text { менту }\end{array}$ & $\begin{array}{c}\text { Після } \\
\text { експери } \\
\text { менту }\end{array}$ & $t$ & $P$ & $\begin{array}{c}\text { До } \\
\text { експери } \\
\text { менту }\end{array}$ & $\begin{array}{c}\text { Після } \\
\text { експери } \\
\text { менту }\end{array}$ & $t$ & $P$ \\
\hline 1. & $\begin{array}{l}\text { Ведення } \\
\text { м’яча, м }\end{array}$ & $\begin{array}{l}11,62 \\
\pm 0,22\end{array}$ & $\begin{array}{l}11,34 \\
\pm 0,35\end{array}$ & 0,67 & $>0,05$ & $\begin{array}{l}11,65 \\
\pm 0,24\end{array}$ & $\begin{array}{c}10,38 \\
\pm 0,18\end{array}$ & 4,23 & $<0,001$ \\
\hline 2. & $\begin{array}{c}\text { Передача } \\
\text { м’яча в } \\
\text { стіну, } 30 \text { с. } \\
\text { (заг. к-ть) }\end{array}$ & $\begin{array}{l}27,04 \\
\pm 2,48\end{array}$ & $\begin{array}{l}30,40 \\
\pm 2,27\end{array}$ & 0,10 & $>0,05$ & $\begin{array}{l}27,33 \\
\pm 1,76\end{array}$ & $\begin{array}{l}34,19 \\
\pm 1,35\end{array}$ & 3,09 & $<0,01$ \\
\hline 3. & $\begin{array}{c}\text { Штрафні } \\
\text { кидки } \\
\text { (заг. к-ть) }\end{array}$ & $\begin{array}{l}4,20 \\
\pm 0,70\end{array}$ & $\begin{array}{l}5,30 \\
\pm 0,56\end{array}$ & 1,22 & $>0,05$ & $\begin{array}{l}4,29 \\
\pm 0,74\end{array}$ & $\begin{array}{c}6,41 \\
\pm 0,59\end{array}$ & 2,23 & $<0,05$ \\
\hline
\end{tabular}

Отже, спеціально підібрані комбінації з використанням рухливих ігор, ігрових вправ та естафет сприяють підвищенню рівня технічної підготовленості юних гандболістів. Аналіз підсумкових показників у експериментальній групи виявив достовірний приріст, відповідний 5\%-му рівню значущості за показниками виконання штрафних кидків і пересування в захисній стійці гандболіста. Середньо-групові значення влучності виконання штрафних кидків зросли на 49,5\%, а середня швидкість переміщення в захисній стійці гандболіста після закінчення експерименту зросла на 8,3\%. Показник передачі 
м'яча в стінку в експериментальній групі збільшився на 25,1\%, що свідчить про достовірний приріст результату при $\mathrm{P}<0,01$.

Висновки. Таким чином, в результаті порівняльного аналізу зроблено наступні висновки.

1. Гандболісти експериментальної групи мали більш високий рівень розвитку технічної підготовленості, ніж їх однолітки з контрольної групи.

2. В контрольній групі також відбулися позитивні зміни в показниках технічної підготовленості, проте вони не були статистично значущими.

3. Отримані в ході експерименту результати підтвердили ефективність розробленої нами методики занять з цілеспрямованим використанням рухливих ігор, ігрових вправ та естафет на початковому етапі навчання юних гандболістів.

Перспективи подальших розвідок полягають у дослідженні впливу рухливих ігор на підготовленість гандболістів 13-14 років.

\section{Jimepamypa}

1. Безверхня Г.В., Семенов А. А., Килимистий М. М., Маслюк Р. В. Рухливі ігри з методикою викладання: навч. посібник. Умань: ВПЦ «Візаві». $2014104 \mathrm{c}$.

2. Гандбол. Навчальна програма для дитячо-юнацьких спортивних шкіл, спеціалізованих дитячо-юнацьких шкіл олімпійського резерву, шкіл вищої спортивної майстерності із змінами: Київ, 2003. 147 с.

3. Дорошенко Э.Ю. Управление технико-тактической деятельностью в командных спортивных играх: [монография]. Запорожье: ООО «ЛИПС» ЛТД, 2013. $436 \mathrm{c}$.

4. Игнатьева В.Я. Гандбол: учебник. М.: Физическая культура. 2008. 384 c.

5. Карасєвич С. А., Карасєвич М. П. Рухливі ігри та ігрові вправи: навчальний посібник. Умань: Видавець «Сочінський М. М.», 2019. 146 с.

6. Корносенко О.К., Бондаренко В.В., Хоменко П.В. Теорія і методика викладання рухливих ігор і забав: навч. посіб. для студ. вищ. навч. закладів. Полтава, 2012. 312 с.

7. Костюкевич В.М. «Теорія і методика спортивної підготовки» (на прикладі командних ігрових видів спорту). Навчальний посібник. Вінниця: Планер, 2014. 616 с.

8. Корягін В. До питання індивідуалізації навчання юних спортсменівігровиків. Physical Education, Sport and Health Culture in Modern Society. 2016. №3(27), 129-135. URL: https://sport.eenu.edu.ua/index.php/sport/article/view/311.

9. Кругляк О. Рухливі ігри та естафети в школі. Посібник для вчителя. Тернопіль: Підручники і посібники, 2004. 80 с.

10. Кубраченко А.Г., Ткачук В.Г. Гандбол: учеб.для высших учеб. завед. систем. физ. воспит. и спорта. К., 2010. 416 с.

11. Левкін В.І., Кудріна Н.В., Згоба В.Л. Теорія і методика викладання гандболу: метод. посіб. для студ. Львів: ЛДУФК, 2011. 136 с. 
12. Любовский Ю. С. Гандбол [Електронний ресурс] / Ю. С. Любовский. - URL: http://www.masters.donntu.edu.ua/2007/fema/lubovskii/ind/ind.htm

13. Методика подготовки гандболистов на основе их анатомофизиологических и индивидуальных особенностей: [учеб. пособие]. Ред. А. П. Попович, Г. И. Мехович, Т. А. Коломийчук, С. Д. Кунышева, Е. А. Гончарова. Екатеринбург : Изд-во Урал. ун-та, 2016. 136 с.

14. Соловей О.М., Соловей Д.О. Основи навчання тактики гри в гандбол [навчально-методичний посібник]. Дніпро, 2018. 112 с.

15. Спортивні ігри: навчальний посібник для вищ. навч. закладів: у 2 т. Ред. Ж. Л. Козіна. Т. 1 : Загальні основи теорії і методики спортивних ігор. Харків: Точка, 2010. $200 \mathrm{c.}$

16. Guerrero J. Handball at school. Handball. Peryodical. №1. 2003. P. 67-70.

17. Hjorth S. Handball schools in Denmark. Handball. Peryodical. № 2. 2004. P.77-79.

\section{References}

1. Bezverkhnia, H. V., Semenov, A. A., Kylymystyi, M. M., \& Masliuk, R.V. (2014). Rukhlyvi ihry $z$ metodykoiu vykladannia [Active Games with Teaching Methods]. Uman: VPTs «Vizavi». (in Ukrainian).

2. Handbol. Navchalna prohrama dlia dytiacho-yunatskykh sportyvnykh shkil, spetsializovanykh dytiacho-yunatskykh shkil olimpiiskoho rezervu, shkil vyshchoi sportyvnoi maisternosti iz zminamy [Handball. Curriculum for children and youth sports schools, specialized children and youth schools of the Olympic reserve, schools of higher sportsmanship with changes]. (2003). Kyiv. (in Ukrainian).

3. Doroshenko, E.Yu. (2013). Upravlenie tekhniko-takticheskoi deiatelnostiu $v$ komandnykh sportivnykh igrakh [Management of technical and tactical activities in team sports games]. Zaporozhe: OOO «LYPS» LTD. (in Russian)

4. Yhnateva, V.Ya. (2008). Handbol [Handball]. M.: Fyzycheskaia kultura. (in Russian).

5. Karasievych, S.A., \& Karasievych, M.P. (2019). Rukhlyvi ihry ta ihrovi vpravy [Active Games and Game Exercises]. Uman: Vydavets «Sochinskyi M.M.». (in Ukrainian).

6. Kozina, Zh.L. (Ed.). (2010). Sportyvni ihry: Zahalni osnovy teorii $i$ metodyky sportyvnykh ihor [Sports Games: General Fundamentals of Theory and Methods of Sports Games]. (Vol. 1). Kharkiv: Tochka. (in Ukrainian).

7. Kornosenko, O.K., Bondarenko, V.V., \& Khomenko P.V. (2012). Teoriia $i$ metodyka vykladannia rukhlyvykh ihor $i$ zabav [Theory and Methods of Teaching Active Games]. Poltava. (in Ukrainian).

8. Koriahin, V. (2016). Do pytannia indyvidualizatsii navchannia yunykh sportsmeniv-ihrovykiv [On the Issue of Individualization of Training of Young Athletes-Players]. Physical Education, Sport and Health Culture in Modern Society, $3(27)$, 129-135. Retrieved from https://sport.eenu.edu.ua/index.php/sport/article/view/311. (in Ukrainian). 
9. Kostiukevych, V.M. (2014). "Teoriia i metodyka sportyvnoi pidhotovky» (na prykladi komandnykh ihrovykh vydiv sportu) ["Theory and methods of sports training" (on the example of team games)]. Vinnytsia: Planer. (in Ukrainian).

10. Kruhliak, O. (2004). Rukhlyvi ihry ta estafety v shkoli. Posibnyk dlia vchytelia [Active Games and Relays at School. Teacher's Guide]. Ternopil: Pidruchnyky i posibnyky. (in Ukrainian)

11. Kubrachenko, A.H., \& Tkachuk, V.H. (2010) Handbol [Handball]. Kiev. (in Ukrainian).

12. Levkin, V.I., Kudrina, N.V., \& Zghoba, V.L. (2011). Teoriia i metodyka vykladannia handbolu [Theory and Methods of Teaching Handball]. Lviv: LDUFK. (in Ukrainian).

13. Liubovskyi, Yu.C. (2007). Handbol [Handball]. Retrieved from http://www.masters.donntu.edu.ua/2007/fema/lubovskii/ind/ind.htm (in Ukrainian).

14. Popovich, A.P., Mekhovich, G.I., Kolomiichuk, T.A., Kunysheva, S.D., \& Goncharova, E.A. (Eds.). (2016). Metodika podgotovki gandbolistov na osnove ikh anatomo-fiziologicheskikh $i$ individualnykh osobennostei [Methodology for Training Handball Players Based on Their Anatomical, Physiological and Individual Characteristics].Yekaterinburg: Izd-vo Ural. un-ta. (in Russian).

15. Solovei, O.M., \& Solovei, D.O. (2018). Osnovy navchannia taktyky hry v handbol [Basics of Learning Handball Tactics]. Dnipro. (in Ukrainian).

16. Guerrero, J. (2003). Handball at school. Handball. Peryodical, 1, 67-70.

17. Hjorth, S. (2004). Handball schools in Denmark. Handball. Peryodical, 2 , 77-79. 